\title{
How External Auditors Detecting Financial Corruption and Fraud in Financial Statement "A Case Study of Jordanian Companies"
}

\author{
Dr. Mustafa A.A. AL-Qudah \\ Shaqra University \\ P. O. Box: 1040, Al-Dawadmi 11911 \\ Saudi Arabia
}

\begin{abstract}
The study aimed to identify the Methods of the external auditors for detecting financial fraud in the financial statement for Jordanian public shareholding companies from the perspective of company's managers, financial managers, external auditor and accountant, working in these companies. To achieve this goal questionnaire was distributed to a random sample of the study population consisting of company's managers, financial managers, external auditor and accountant, working in these companies. The study finds that there is reasonable realization among the external auditors in Jordan about their responsibility for discovering financial corruption and fraud. The study showed that the obstacles affect the external auditor's ability to perform their professional responsibility, and it also find that external auditor's apply and follow the methods and procedures such as International Accounting Standard, Jordanian laws and regulations, to discover fraud and corruption cases.
\end{abstract}

Keywords: External auditor, detecting financial corruption, detecting financial corruption and fraud, detecting fraud in the financial statement for the Jordanian companies.

\section{Introduction}

In the modern business world, characterize with the high level of technology fraud and corrupt practices increased, and new and complicated legislation which offers new opportunities for both the perpetrators of fraud and forensic accountants. It is the responsibility of the management of every organization in the public sector environment to put in place adequate measures of control to strengthen its activities and imbibe good corporate governance practices. Financial statement fraud is one of the biggest challenges in the modern business world, when corporations engage in certain practices. Financial statement fraud may be committed by the senior and mid-level management of the corporation to fraudulently enhance the financial health of a business and enrich one's own net worth.

Fraud is a serious problem and is often given special attention in the field of accounting and auditing. To be fair, a financial statement overall must be free from material misstatement, caused by fraud or error. Because of the basic nature of fraud which is complex and dynamic, so that as the times progressed, it encourages more diverse fraud. Fraud is very detrimental both to the organization and to the economy (Zimbelman et al., 2014).

Financial statement fraud is deliberate misrepresentation, misstatement or omission of financial statement data. Top management is usually at the center of financial statement fraud because financial statements are created at the management level. Financial statement serves as a tool for communicating to users and stakeholders the true and fair view of the company. Financial statement shows where the company is, and where it is heading. (Weygandt and Warfield, 2007) assert that financial statements are useful for the assessment of a company's liquidity, solvency, financial flexibility and performance.

International Standard on Auditing (ISA 240), defined Fraud as an intentional act by one or more individuals among management, those charged with governance, employees, or third parties, involving the use of deception to obtain an unjust or illegal advantage.

Financial statement fraud is a deliberate misstatement of material facts by management in the books of accounts of a company with the aim of deceiving investors and creditors. This illegitimate task performed by management has a severe impact on the economy because it significantly dampens the confidence of investors. (Spathis, 2002) notes that, regardless of the type of company, the percentage of financial statements that contained fraud in information is quite high. Against this background, researchers, management, lenders, workers, suppliers, clients and the community at large have demonstrated a great interest in the detection fraud in financial statements. There are strong research concerns for detecting fraud in financial statement. 


\section{Study Problem}

Different papers discussed the nature and role of the external auditor in meeting the needs of users of the financial statement, where it can be said that there is growing trend criticizes the performance and results of the auditor work, because of the lack of clarity and ambiguity in auditors role, in the minds of the users, as the recent years have seen lawsuits against major audit institutions, for failing to detect cases of financial fraud and corruption, by giving a clean reports.

The problem of the study lies on the lack of clarity of the responsibility of the external auditor concerning the auditors detection fraud and corruption cases, and what increases this lack of clarity is the absence of legal and administrative legislations by governments, and international organizational audit institution, that states the responsibility of the external auditor in discovering the financial fraud and corruption cases, which resulting in defect of the audit procedures, and finally audit report.

The responsibility of the Audit Bureau in Jordan is to maintain and control public funds; this requires using analytical methods and tools to supervise, examine, audit, and review the accounting operations in these institutions.

Therefore, the Study Problem can be summarized to answer the following questions:

1) What is the responsibility of the external auditor to discover financial fraud and corruption cases?

2) What are the obstacles that affect the liability of the external auditors in their performance of professional responsibility?

3) What are the methods and procedures followed by the auditor to reduce the audit risk in order to discover fraud and corruption cases?

\section{Objectives of the study:}

This study aimed to achieve the following objectives:

1) To identify the extent of commitment that the external auditors comply with international auditing standards relating to discover fraud and corruption cases.

2) Determine the responsibility of the external auditor to avoid the obstacles that affect the liability of the external auditors in their performance of professional responsibility

3) Identify the methods and procedures followed by the auditor in the detection cases of fraud.

\section{Literature review}

When we hear the term risk, we usually think of the financial institutions whose mismanagement of risk was instrumental in causing the 2008 financial crash, which threaten to harm the institutions and their ability to fulfill their missions. Today, as higher education institutions face increasing levels of scrutiny and competition for government funding, it is imperative that they focus more on assessing, preventing and managing the risks they face (Ujal, Amit, Hiral \& Rajal, 2012). Issues such as fraud or intentional or unintentional loss of nonpublic personal information can reverberate quickly, especially in an age of social media and networks, and harm the reputation of an institution (Brennan, N., \& McGrath, C., 2007).

Practical significance Concerns of fraud have been as long as written records have been kept and record keeping. Many of the fraud literature starts with a recitation of infamous accounting (Clikeman, 2009) and corporate scandals and frauds (Punch, 1996), which often excite public interest and concern. Concern with fraud affects public confidence in institutions as diverse as stock markets, auditors, bankers, corporate executives and government (Sanders et al., 1996). External auditor's objectives are summarized to determine whether the accounting records are accurate and complete, prepared in accordance with the provisions of GAAP, financial statements are prepared from the accounts present fairly the corporation's financial position (Persons, O. 2005).

\subsection{Factors to reduce the risk of financial fraud and corruption}

Factors that should reduce the risk of financial fraud and corruption can be summarized in the following (Arens, Elder, and Beasley, 2014):

1) Assess internal and external risks, and conduct thorough background checks.

2) Get commitment from top management; Company's Board of Directors, Senior Executives, or Owners to develop the company's policy and guidelines against corruption.

3) Establish controls over promotional expenses, travel, entertainment, sponsorships.

4) Make sure that everybody knows the procedures, the company's principles and policies need to be stated clearly.

5) Monitor compliance and review procedures regularly

\subsection{Rights and duties of the external Auditor in Jordanian law:}


According to the Jordanian Law of auditing profession No. 32 for the year 1985, in article number (20), states the rights of the auditor; "the auditor has the right to give advice and professional experience, and do arbitration and expertise in accounting, financial and tax fields, In addition to testing and auditing the accounts of the individuals, companies, institutions and bodies, also the law in article number (21) and (22) stipulates the following:

1) The general assembly shall elect one or more licensed auditor/s to perform an external audit of the company in accordance with the international auditing standards, the requirements and rules of the profession, and the legislations in force.

2) The external auditor shall exercise his duties for one year renewable, provided that the renewal for the partner at the external auditor may not be for more than four consecutive years, and the re-election may not take place before a minimum of two years. (Jordanian Corporate Governance Code, page 18)

3) The company shall take appropriate actions to ensure the following:

A. The company's external auditor is not a founder, a shareholder, a member of its board of directors, or a partner or an employee of any member of the board of directors.

B. The external auditor does not perform any additional services to the company such as administrative or technical consultations.

C. The external auditor is independent in accordance with international auditing standards.

D. The external auditor performs his duties impartially without interference from the board of directors or the executive management.

4) The company is not allowed to appoint any employee of the external auditor office in the company's upper management before at least one year from the date of his employment termination at the auditor's office.

5) The company's external auditor should:

A) Possess a valid license to practice the profession.

B) Be a member of the Jordan Association of Certified Public Accountants.

C) Have practiced the profession on a full time basis for at least three consecutive years, after receiving his license to practice the auditing profession.

D) Have in his firm at least one partner or employee who must also meet the above- mentioned requirements.

5.3 External auditor's duties (Jordanian Law of auditing profession No. 32 for the year 1985):

A) Performing the duties assigned to him in impartiality and independence, and monitoring the company's operations.

B) Auditing the company's accounts in accordance with international standards and the accepted profession rules.

C) Examining the financial, administrative, and internal auditing systems of the company and submitting his opinion on their effectiveness and ensuring their suitability for the company's business and safeguarding of its assets.

D) Verifying ownership of the company's assets and the legality of its obligations.

F) Attending meetings of the company's general assembly.

E) Answering questions and inquiries from shareholders with regard to the financial statements and closing accounts, at the general assembly meetings.

F) Expressing opinion on the fairness of the company's financial statements, and to ask for their amendment if there is anything that affects their fairness.

G) Reporting to the authorities concerned any violation of the law, or any financial or administrative issues that affect the company's situation negatively

\section{Previous study}

(Kassem \& Higson, 2012) The study focused on two areas. Firstly, it explores the reasons behind the audit expectation gap, and secondly, it assesses the efforts of standards' setters and external auditors to narrow the gap in relation to fraud detection. The paper provides a set of recommendations to regulators and external auditors in an effort to fight fraud., specifically it appears that external auditors still need guidance on how to rank risk factors while considering the likelihood of fraud to the business, impact of the fraud if it occurs, and pervasiveness of the fraud if found.

(Al-Khaddash, Al Nawas \& Ramadan, 2013) the paper focuses on identifying the most important factors affecting audit quality in Jordanian Commercial Banks (JCBs). The perceptions of JCBs' internal and external auditor's in addition to financial managers have been investigated. In general it was found that the respondents believe that audit quality in the Jordanian banking sector ranges from satisfactory to very good. The results indicate a positive and significant correlation between audit quality and audit efficiency, the reputation of auditing office, auditing fees, the size of audit firm, and the proficiency of auditor. The results of the study make a contribution to existing literature in the area of factors affecting audit quality in eastern developing countries such as Jordan. 
In addition, their research adds further evidence to the value of studying auditing efficiency, the reputation of audit firm, auditing fees, the size of auditing office, and the proficiency of auditor on the quality of auditing. (Alshboul \& Alrabba, 2014) The purpose of the study was to assess the effectiveness of analytical procedures that are used by the Jordanian Audit Bureau in the audit process to discover accounting fraud in public institutions. In particular, the study focused on identifying what types of fraud are detected and what types of fraud are missed by the analytical tools.

The study attempted to address the challenges and obstacles that the Audit Bureau faces when detecting fraud. The responsibility of the Audit Bureau in Jordan is to maintain and control public funds; this requires using analytical methods and tools to supervise, examine, audit, and review the accounting operations in these institutions. Using a convenience sampling method, the research surveyed 100 auditors in Jordan in order to assess the effectiveness of analytical procedures that are used by the Jordanian Audit Bureau in the audit process to discover accounting fraud in public institutions. The findings of the study revealed that the efficiency of the current Jordanian Audit Bureau analytical tools to detect accounting fraud in public institutions has a significant effect on the occurrence of accounting fraud in Jordanian institutions. In addition, sufficiency of the current Jordanian Audit Bureau analytical tools to detect accounting fraud in public institutions has a significant effect on the occurrence of accounting fraud in Jordanian institutions. The results also indicated that more experienced auditors tend to agree that more analytical tools are still needed to combat accounting fraud, and damaged corporate reputation increases accounting fraud.

(Aksoy \& Kahyaoglu, 2012) the paper focus on the perspectives of executive managers has been analyzed to evaluate the potential determinants of fraud cases in Turkey. The analysis integrates the theory of the fraud triangle, which states that corporate fraud is a function of incentives, opportunities and attitudes/rationalizations, and the corporate governance (CG) principles. Auditing regulation (AICPA, 1988, 1997, 2002) has outlined frequent fraud indicators and related risk factors. These indicators are also called "red flags" and correspond to possible signs within an organization's business environment which indicate a higher risk of an intended misstatement of the financial statements. This paper tries to provide empirical evidence on the determinants of fraud cases in Turkey based on the executive managers' current experiences and perspectives related to fraudulent cases they witnessed in business environment. The data is obtained from (146) executive managers from prominent companies in various sectors by interviewing with them to complete the questionnaires or online surveys. The data is analyzed by using Logit Models to assess the empirical findings.

The Logit model results of fraud survey in Turkey indicate that the probability of at least one fraud case occurring in a company is estimated at $2.4 \%$. The relation between the probability of fraud case occurring in a company and the existence of procedure and policy, the amount of fraud case, the revenue level, labor and being publicly traded is an inverse relationship, which means that if a company is having a policy and procedure, increasing revenue and labor size and also publicly traded then, the probability of having fraud case $2.4 \%$. In the contrary case, if these conditions do not exist for a company, then the probability of having a fraud case will be \%97.6. The variables used in the fraud model are also good indicators of corporate governance for a company. In other words, if a company is having above mentioned conditions then the probability of having a fraud case will be less likely. The marginal effects of each explanatory variable are also estimated and the results are parallel to the relevant literature. Briefly, all variables contained in the model influence the probability of having a fraud case in Turkey, i.e. the degree of corporate governance implementation increase under these conditions.

(Omoye \& Eragbhe, 2014) The paper investigated accounting ratios and false financial statements detection among firms quoted in the Nigerian Stock Exchange. Accounting data were obtained from the reported financial statements of 30 sampled firms in financial and non financial sectors covering a time frame of five (5) years (2007-2011).The statistical instrument employed was Pooled Data Binary Logit regression. Data collected were run with E-Views 7 and SPSS 20. The findings revealed that investment and liquidity ratios were significantly related to financial statements fraud. It was recommended that accounting ratios should be critically examined by investors and stakeholders so as to detect probabilities of financial statements fraud occurrences, and also Government regulatory authorities like the Nigerian Stock Exchange, Security and Exchange Commission, Central Bank of Nigeria, Financial Reporting Council of Nigeria and others should ensure that financial statements of firms are properly screened and endorsed by them before being released to the public.

\section{Study Hypotheses:}

H01: There isn't any responsibility of the external auditor to discover financial fraud and corruption cases?

H02: There aren't any obstacles that affect the liability of the external auditors in their performance of professional responsibility?

H03: There aren't any methods and procedures followed by the external auditor to reduce the audit risk in order to discover fraud and corruption cases? 


\section{Research methodology:}

To achieve the objectives of the study the researcher followed the descriptive and analytical statistical techniques.

\subsection{Study model}

Based on the research objectives and literature review, the researcher has developed a model as shown in Figure 1.

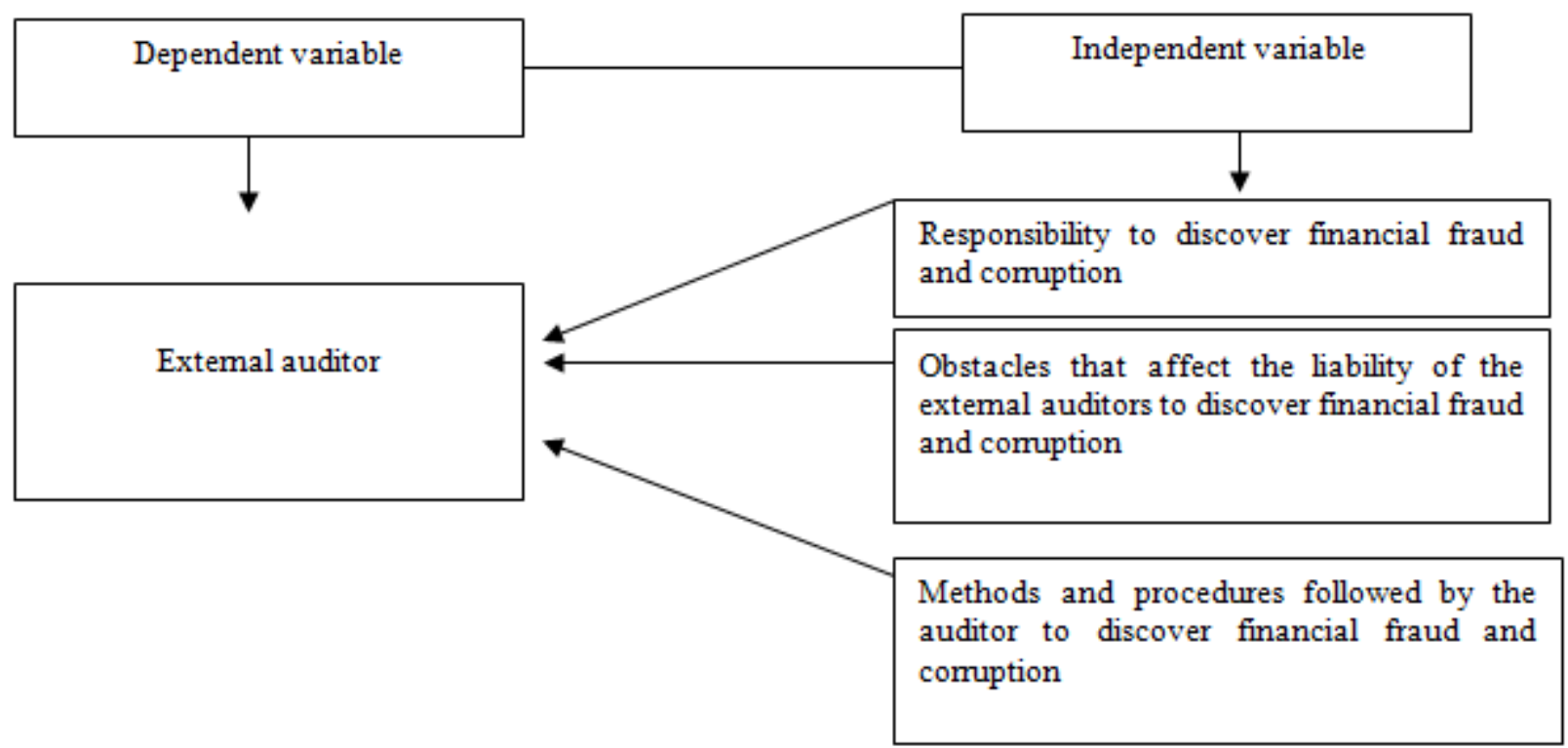

Figure 1: Study model

\subsection{Research Population and sample}

The study population consists of; company's managers, financial managers, external auditor and accountant, in the Jordanian public shareholding companies, the sample consist of all of these companies. Ninety (90) questionnaires were distributed to company's managers, financial managers, external auditor and accountant; Eighty (80) questionnaires were returned and valid for statistical analysis, with the response rate of $89 \%$.

\subsection{Data Collection}

The researcher depended on gathering primary and secondary data. Secondary sources were literature review such as journals, books, and internet. The instrument used for the collection of the primary data was a questionnaire.

Questionnaire consisted of two parts; Part one: Demographic characteristics, including academic specialization, educational qualification and working experience, Part two: The questionnaire was adjusted to fifteen questions. A Likert five-point scale ranges from "strongly disagree" to "strongly agree" was used to examine participants' responses to questionnaire statements. The questionnaire included ten dimensions, which are illustrated in tables 4 , and 5.

\subsection{Measuring Instrument}

To achieve the objectives of the study the researcher followed the descriptive and analytical statistical techniques were applied in the analysis by using Statistical Package of Social Sciences (SPSS), mean, standard deviation, percentage and frequency, T-test was applied to test the study hypotheses, in order to identify the methods of the external auditors for detecting financial corruption and fraud in the financial statement for the Jordanian public shareholding companies. A Likert five-point scale ranges from "strongly disagree" to "strongly agree" was used to examine participants' responses to questionnaire statements, and answers were ranged between strongly agree, agree, somewhat agree, disagree, and strongly disagree. The reliability test was applied to examine the internal consistency of the research instrument. The questionnaire was piloted with a similar sample of respondents selected from Jordanian public shareholding companies. The aim was to assess the applicability of the questionnaire and the readability of its items. The internal consistency reliability of each of the dimensions was assessed by Cronbach's alpha test.

The alpha values for all dimensions vary from $88.1 \%$ to $91.8 \%$, which are considered acceptable and confirms the reliability of the questionnaire as it's shown in table (1), (Sekaran, 2003). 
Table 1: Cranach's Alpha for the Scale

\begin{tabular}{|l|l|c|l|}
\hline Hypothesis & \multicolumn{1}{|c|}{ Description } & $\begin{array}{l}\text { Number of } \\
\text { Questions }\end{array}$ & $\begin{array}{l}\text { Cronbach's } \\
\text { alpha }\end{array}$ \\
\hline $\begin{array}{l}\text { First } \\
\text { Hypothesis }\end{array}$ & $\begin{array}{l}\text { There isn't any responsibility of the external auditor to discover } \\
\text { financial fraud and corruption cases? }\end{array}$ & 5 & $\% 88.1$ \\
\hline $\begin{array}{l}\text { Second } \\
\text { Hypothesis }\end{array}$ & $\begin{array}{l}\text { There aren't any obstacles that affect the liability of the external } \\
\text { auditors in their performance of professional responsibility? }\end{array}$ & 5 & $\% 91.8$ \\
\hline $\begin{array}{l}\text { Third } \\
\text { Hypothesis }\end{array}$ & $\begin{array}{l}\text { There aren't any methods and procedures followed by the external } \\
\text { auditor to reduce the audit risk in order to discover fraud and } \\
\text { corruption cases? }\end{array}$ & 5 & $\% 91.2$ \\
\hline
\end{tabular}

\section{Data Analysis Method}

Table (2) shows the distribution of the sample according to their Business Certification, Academic Major, Educational Level, and Working Experience. The table illustrates that 39\% of the respondents holding JCPA, while the highest percentage of the respondents according to their Academic Major was Accounting 50\%, with a $62 \%$ the respondents held a bachelors' degree in accounting, and $54 \%$ had working experience of 21 - 25 years. In general, the previous results suggest that respondents are able to absorb the questionnaire and provide reliable information.

Table (2): Descriptive Statistics

\begin{tabular}{|l|l|l|l|}
\hline \multirow{4}{*}{ Independent Variable } & Type of Independent Variable & Frequency & Percentage \\
\hline \multirow{5}{*}{ Business Certification } & JCPA & 31 & $\% 39$ \\
\cline { 2 - 4 } & CMA & 29 & $36 \%$ \\
\cline { 2 - 4 } & CPA & 15 & $19 \%$ \\
\cline { 2 - 4 } & Others & 5 & $6 \%$ \\
\hline \multirow{5}{*}{ Educational Level } & Accounting & 40 & $50 \%$ \\
\cline { 2 - 4 } & Finance and banking & 20 & $25 \%$ \\
\cline { 2 - 4 } & Business management & 15 & $19 \%$ \\
\cline { 2 - 4 } & Others & 5 & $6 \%$ \\
\hline \multirow{5}{*}{ Working Experience } & Diploma Degree & 15 & $19 \%$ \\
\cline { 2 - 4 } & Bachelors Degree & 50 & $62 \%$ \\
\cline { 2 - 4 } & Master Degree & 15 & $19 \%$ \\
\cline { 2 - 4 } & Less than 15 Years & 17 & $21 \%$ \\
\cline { 2 - 4 } & 21-20 25 & 15 & $64 \%$ \\
\cline { 2 - 4 } & Above 26 & 43 & $100 \%$ \\
\hline Total & Each Type of Independent Variable & 80 & \\
\hline
\end{tabular}

Table (3) shows the distribution of the sample according to their Position, company's managers, financial managers, external auditor and accountant. The highest percentage were accountant with a percentage of (33\%) followed by Financial Manager with a percentage $(30 \%)$ Followed by external auditor with a percentage (25\%) followed by company's managers with a percentage $(12 \%)$, this is an indication that the respondents are qualified in terms of financial and administrative disciplines, and this gives them the ability to perceive the administrative accounting practices, therefore, it gives them an advantage in the ability to deal with external auditors for detecting financial corruption and fraud in the financial statement in Jordanian public shareholding companies.

Table (3) Descriptive Statistics

\begin{tabular}{|l|l|l|}
\hline Certification & Frequencies & Percentage \\
\hline Company's Managers & 10 & $12 \%$ \\
\hline External Auditors & 20 & $25 \%$ \\
\hline Financial Managers & 24 & $30 \%$ \\
\hline Accountants & 26 & $33 \%$ \\
\hline Totals & $\mathbf{8 0}$ & $\mathbf{1 0 0 \%}$ \\
\hline
\end{tabular}




\section{Results of descriptive statistics for the variables of the study}

Table (4) used both the mean and standard deviation to show the degree of effect of the responsibility for the external auditor to detect cases of financial corruption and fraud in Jordanian public shareholding companies, which was relatively high in total in accordance to the descriptive statistics, which indicate that external auditor is responsible to detect cases of financial corruption and fraud.

Table (4) Descriptive Statistics (mean and Standard Deviation)

The responsibility of external auditor to detect cases of financial corruption and fraud

\begin{tabular}{|l|l|l|l|}
\hline The statement item & Mean & $\begin{array}{l}\text { Standard } \\
\text { deviation }\end{array}$ & $\begin{array}{l}\text { levels } \\
\text { realization }\end{array}$ \\
\hline $\begin{array}{l}\text { The external auditor responsible for discovering the financial corruption } \\
\text { and fraud. }\end{array}$ & 4.1000 & 0.78807 & High \\
\hline $\begin{array}{l}\text { The external auditor responsible for the prevention of financial corruption } \\
\text { and fraud. }\end{array}$ & 4.1500 & 0.74516 & High \\
\hline $\begin{array}{l}\text { The external auditor responsible for the acts performed in charge of the } \\
\text { audit process. }\end{array}$ & 4.2500 & 0.85070 & High \\
\hline $\begin{array}{l}\text { The external auditor responsible for discovering illegal acts undertaken by } \\
\text { the company. }\end{array}$ & 4.2500 & 0.85070 & High \\
\hline $\begin{array}{l}\text { The external auditor careless in his duties when financial corruption and } \\
\text { fraud discovered later. }\end{array}$ & 4.1500 & 0.74516 & High \\
\hline
\end{tabular}

Table (5) used both the mean and standard deviation to show the degree of effect of the obstacles affecting the ability of the external auditor in their responsibility of professional performance in Jordanian public shareholding companies, which was relatively high in total in accordance to the descriptive statistics, Which indicate that there is a high level of the obstacles affecting the ability of the external auditor in practicing their responsibility of professional performance.

Table (5) Descriptive Statistics (mean and Standard Deviation) show the obstacles affecting the ability of the external auditor in their responsibility of professional performance

\begin{tabular}{|l|l|l|l|}
\hline The statement item & Mean & $\begin{array}{l}\text { Standard } \\
\text { deviation }\end{array}$ & $\begin{array}{l}\text { levels of } \\
\text { realization }\end{array}$ \\
\hline Lack of understanding the role of external auditor. & 4.1000 & 0.78807 & High \\
\hline $\begin{array}{l}\text { Lack of development and improve the performance of external } \\
\text { auditor by participating in audit training courses. }\end{array}$ & 4.1500 & 0.74516 & High \\
\hline $\begin{array}{l}\text { Inadequate audit fees charged by the auditor. } \\
\begin{array}{l}\text { Lack of client's carefulness in audits for difficulty in the } \\
\text { financial position. }\end{array}\end{array}$ & 4.1000 & 0.85070 & High \\
\hline $\begin{array}{l}\text { The lack of agreement with the client on the duties and } \\
\text { responsibilities in the audit function. }\end{array}$ & 4.1000 & 0.78807 & High \\
\hline
\end{tabular}

Table (6) used both the mean and standard deviation to show the degree of effect of the methods and procedures followed by the external auditor to reduce the audit risk in order to discover fraud and corruption cases in Jordanian public shareholding companies, which was relatively high in total in accordance to the descriptive statistics, Which indicate that the external auditor realized methods and procedures that should be followed by them to reduce the audit risk in order to discover fraud and corruption cases.

Table (6) Descriptive Statistics (mean and Standard Deviation) show methods and procedures followed by the external auditor to reduce the audit risk in order to discover fraud and corruption cases

\begin{tabular}{|l|l|l|l|}
\hline The statement item & Mean & Standard deviation & levels of realization \\
\hline $\begin{array}{l}\text { Attend meeting of the management and the Audit } \\
\text { Committee when it held. }\end{array}$ & 4.1000 & 0.74516 & High \\
\hline $\begin{array}{l}\text { Inquire about the company's attorney for lawsuits filed } \\
\text { against the company. }\end{array}$ & 4.2500 & 0.85070 & High \\
\hline $\begin{array}{l}\text { Discovering fraud and corruption will narrow the } \\
\text { expectations gap. }\end{array}$ & 4.2500 & 0.85070 & High \\
\hline $\begin{array}{l}\text { Inquire from senior management if they have any } \\
\text { knowledge about the existence of fraud and corruption. }\end{array}$ & 4.1500 & 0.74516 & High \\
\hline $\begin{array}{l}\text { Inquire and ask the administration when fraud and } \\
\text { corruption was discovered. }\end{array}$ & 4.1000 & 0.78807 & High \\
\hline
\end{tabular}




\section{Results of testing the hypothesis}

Table (7) shows the results of testing the first hypothesis (One sample T- test). H01: There isn't any responsibility of the external auditor to discover financial fraud and corruption cases? The first hypothises of the study was tested using simple regression analysis, when signeficannt level $(\mathrm{Sig})(\alpha)<=0.05$, table (7) shows Sig-t is $(0.000)$. Therfore the null hypothises was rejected and the substitute hypothises was accepted. Which means that there is a statistical relationship between corruption and fraud and responsibility of the external auditor, in other words, Which means that the external auditor are responsible for the detection of corruption and fraud in the financial statements.

Table (7) Results of testing the first hypothesis (One sample T- test)

\begin{tabular}{|l|l|l|l|l|}
\hline Independent variable & Tabular T & Calculated T & Sig-t & Statistical result \\
\hline $\begin{array}{l}\text { H01: There isn't any responsibility of } \\
\text { the external auditor to discover } \\
\text { financial fraud and corruption cases? }\end{array}$ & 5.98 & 3.48 & 0.000 & Reject H01 \\
\hline
\end{tabular}

Table (8) shows the results of testing the second hypothesis (One sample T- test). H02: There aren't any obstacles that affect the liability of the external auditors in their performance of professional responsibility?

The second hypothises of the study was tested using simple regression analysis, when signeficannt level $(\operatorname{Sig})(\alpha)<=$ 0.05. Table (8) shows Sig-t is (0.000). Therfore the null hypothises was rejected and the substitute hypothises was accepted. Which mean that there is a statistical relationship between obstacles and the performance of the external auditor, in other words, the obstacles affects the liability of the external auditor in their performance of professional responsibility.

Table (8) Results of testing the second hypothesis (One sample T- test)

\begin{tabular}{|l|l|l|l|l|}
\hline Independent variable & Tabular T & Calculated T & Sig-t & Statistical result \\
\hline $\begin{array}{l}\text { H02: There aren't any obstacles that affect } \\
\text { the liability of the external auditors in their } \\
\text { performance of professional responsibility? }\end{array}$ & 7.89 & 5.48 & 0.000 & Reject H02 \\
\hline
\end{tabular}

Table (9) shows the results of testing the third hypothesis (One sample T- test). H03: There aren't any methods and procedures followed by the external auditor to reduce the audit risk in order to discover fraud and corruption cases?

The third hypothises of the study was tested using simple regression analysis, when signeficannt level $(\mathrm{Sig})(\alpha)<=$ 0.05. Table (9) shows Sig-t is (0.000). Therfore the null hypothises was rejected and the substitute hypothises was accepted. Which mean that there is a statistical relationship between methods and procedures followed and external auditor, in other words, the methods and procedures followed by the external auditor to reduce the audit risk help him to discover fraud and corruption cases.

Table (9) Results of testing the third hypothesis (One sample T- test)

\begin{tabular}{|l|l|l|l|l|}
\hline Independent variable & $\begin{array}{l}\text { Tabular } \\
\mathrm{T}\end{array}$ & $\begin{array}{l}\text { Calculated } \\
\mathrm{T}\end{array}$ & Sig-t & $\begin{array}{l}\text { Statistical } \\
\text { result }\end{array}$ \\
\hline $\begin{array}{l}\text { H03: There aren't any methods and procedures followed by } \\
\text { the external auditor to reduce the audit risk in order to } \\
\text { discover fraud and corruption cases? }\end{array}$ & 5.67 & 4.48 & 0.000 & $\begin{array}{l}\text { Reject } \\
\text { H03 }\end{array}$ \\
\hline
\end{tabular}

\section{Conclusion and Recommendations:}

\subsection{Conclusion:}

This study aims to find out the methods and procedures followed by the external auditors to deduct financial corruption and fraud in the financial statement in Jordanian public shareholding companies, the results can be summarized as follows:

1. The results indicated that the external auditor are responsible for the detection of corruption and fraud in the financial statements, which means that there is a realization among the external auditors in Jordan about their responsibility for discovering financial corruption and fraud.

2. Results of the study showed that obstacles have an impact effect on the external auditor's performance of professional responsibility, which means that the obstacles affect the external auditor's ability to perform their professional responsibility. 
3. Results of the study showed that the external auditors in Jordan apply and follow the methods and procedures such as International Accounting Standard, Jordanian laws and regulations, to discover fraud and corruption cases.

\subsection{Recommendations:}

In light of the results that have been found in this study, the researcher recommends the external auditors to the following:

1. The external auditor should make plan for the audit process using professional skepticism especially in matters that the risk is material which will distorted the financial statements that will lead to financial fraud and corruption .

2. The auditor should obtain adequate understanding of the client to evaluate the role of the management for the possibility of material misstatements, also to understand the accounting and internal control system.

3. When the auditor discovers financial fraud and corruption; the auditor must inform the administration of the company and individuals authorized by the company to take the appropriate action.

\section{References}

Al-Khaddash, H. Al Nawas, R. \& Ramadan, A. (2013) Identifying the most important factors affecting audit quality in Jordanian Commercial Banks. International Journal of Business and Social Science. Vol. (4) 11, 206- 222.

Alshboul, A. \& Alrabba, H. (2014) Assess the effectiveness of analytical procedures that are used by the Jordanian Audit Bureau in the audit process to discover accounting fraud in public institutions. International Journal of Business and Social Science. Vol. 5, No. 11(1), 203-208.

Arens A. Alvin, Elder J., and Beasley S., (2014). Auditing and Assurance Services (15 ${ }^{\text {th }}$ ed.) New York: Pearson.

Brennan, N., \& McGrath, C. (2007). Financial statement fraud; some lessons US and European case studies. Australian Accounting Review, 17(42), 49-61.

Clikeman, P. M. (2009). Called to account: Fourteen financial frauds that shaped the American accounting profession. New York, NY: Routledge

Jordanian Law of Auditing Profession. Law No. 32 for the year 1985, article number (20).

Kassem, R. \& Higson, A. (2012). Financial Reporting Fraud: Are Standards' Setters and External Auditors Doing Enough? International Journal of Business and Social Science Vol. (3) 19, 283 - 290.

Kieso, D., Weygant, J., \& Warfield, T. ( (2007). Intermediate Accounting (12th ed.) New York: John Willey and Sons.

Persons, O. (2005). The Relation between the New Corporate Governance Rules and the Likelihood of Financial Statement Fraud. Review of Accounting and Finance, 4(2), 125-148.

Punch, M. (1996). Dirty business: Exploring corporate misconduct. London, UK: Sage.

Sanders, J., Hamilton, V., Denisovsky, G., Kato, N., Kawai, M., Kozyreva, P. Tokoro, K. (1996). Distributing responsibility for wrongdoing inside corporate hierarchies: Public judgments in three societies. Law \& Social Inquiry, 21(4), 815-855.

Spathis, C. (2002). Detecting False Financial Statements Using Published Data: Some evidence from Greece. Managerial Auditing Journal, 17(4), 179-91.

Ujal, Amit, Hiral \& Rajal (2012). Detection of fraudulent financial statement in India: An exploratory study.4, JanJune.

Zimbelman, Mark F. et al. 2015. Challenges Facing Auditors in Detecting Financial Statement Fraud: Insights from Fraud Investigations. Journal of Forensic \& Investigative Accounting. 7(2): 63-112 